\title{
A standard for low molecular weight heparin?
}

Citation for published version (APA):

Hemker, H. C. (1989). A standard for low molecular weight heparin? Haemostasis, 19, 1-4. https://doi.org/10.1159/000215881

Document status and date:

Published: 01/01/1989

DOI:

$10.1159 / 000215881$

Document Version:

Accepted author manuscript (Peer reviewed / editorial board version)

\section{Please check the document version of this publication:}

- A submitted manuscript is the version of the article upon submission and before peer-review. There can be important differences between the submitted version and the official published version of record.

People interested in the research are advised to contact the author for the final version of the publication, or visit the DOI to the publisher's website.

- The final author version and the galley proof are versions of the publication after peer review.

- The final published version features the final layout of the paper including the volume, issue and page numbers.

Link to publication

\footnotetext{
General rights rights.

- You may freely distribute the URL identifying the publication in the public portal. please follow below link for the End User Agreement:

www.umlib.nl/taverne-license

Take down policy

If you believe that this document breaches copyright please contact us at:

repository@maastrichtuniversity.nl

providing details and we will investigate your claim.
}

Copyright and moral rights for the publications made accessible in the public portal are retained by the authors and/or other copyright owners and it is a condition of accessing publications that users recognise and abide by the legal requirements associated with these

- Users may download and print one copy of any publication from the public portal for the purpose of private study or research.

- You may not further distribute the material or use it for any profit-making activity or commercial gain

If the publication is distributed under the terms of Article $25 \mathrm{fa}$ of the Dutch Copyright Act, indicated by the "Taverne" license above, 


\section{Editorial}
19
Haemostasis 1989:1:1-4
(C) 1989 S. Karger AG, Basel 0301-0147/89/0191-0001\$2.75/0

\section{A Standard for Low Molecular Weight Heparin?}

In the last few years many articles on lowmolecular-weight heparins (LMWH) appeared in this journal, both in regular issues and in supplements. It is therefore not surprising that in the present issue a discussion appears between Drs. Johnson and Fareed on the use of a standard preparation for the comparison of the activities of low molecular weight heparins. The discussion was provoked by two articles from Dr. Fareed's laboratory published in a supplement for Haemostasis [1, 2].

It is a pity that these articles contain more than the inevitable number of typesetting errors. I do feel that, as a main editor, I owe our readers an apology here. The careless presentation is all the more regrettable because it tends to distract the reader from the main issue: Is there a need for a LMWH standard? Can a useful standard be presented at this moment? or rather, What is the use of a standard such as it can be presented at this moment?

The first question must be answered in the affirmative. There is an obvious need for order in this field where 12 or more different preparations are assessed according to at least three different measuring principles, that moreover are applied in an uncounted number of different ways.
The second question, Can a useful standard be presented at this time?, requires some caution. It is at the very heart of the matter that properties that are tightly linked in unfractionated heparin are separated in LMWH. The two properties that everybody wants to see dissociated are antithrombotic efficiency and induction of a bleeding tendency. The two that everybody knows to be separated are antifactor $\mathrm{Xa}$ and antithrombin activity. The latter are not the only properties of heparins and they are surely not the respective indicators of therapeutic efficiency and tendency to bleeding, although this for some time has been a common hope of those interested in the field. In different preparations antithrombin and anti-Xa activity are separated to a different extent, the extremes being Choay's pentasaccharide [3] that has virtually no antithrombin activity whereas some heparinoids may have no anti$\mathrm{Xa}$ activity and a persistent antithrombin activity. Anyhow, it is common knowledge that within the group of LMWH, unlike between unfractionated heparins, the ratio of the two activities varies considerably. It means that any LMWH when compared to any standard will exhibit an activity that is dependent upon the property tested. Of course the people responsible for the estab- 
lishment of the NIBSC standard are completely aware of this, and that is why they standardize on well-defined properties such as the antifactor $\mathrm{Xa}$ activity. It is the gist of the Fareed articles that they show that apart from antithrombin and anti-Xa activities several other properties of LMWH vary independently in different preparations, as was quite reasonable to suspect.

It is essentially unknown which of the properties of heparin is (are) the pharmacologically important one(s). There is good reason to assume that it is not the anti-Xa activity because it has been shown that in plasma, acting on endogenously activated factors, unfractionated heparin, which cannot be denied antithrombotic activity, has no antiprothrombinase action to speak of $[4,5]$. As factor $\mathrm{Xa}$ is the active site carrier in prothrombinase, this means that in plasma and therefore in all probability, in vivo, the anti-factor $\mathrm{Xa}$ action is of no key pharmacological importance.

Several perfectly efficient LMWH show hardly any antiprothrombinase activity in plasma either. Only in a drug such as Choay's pentasaccharide can the antiprothrombinase (i.e. the physiological anti-Xa) action be shown to be of importance in plasma. In that case the inhibition of prothrombinase leads to a secondary inhibition of thrombin by inhibiting its generation and not by increasing its scavenging. The fact that the pentasaccharide has been shown to be (mildly) antithrombotic in animals [6] therefore does not proove that anti-Xa action is pharmacologically important. Anti-Xa action always implies lower effective thrombin production, whereas the reverse is not true.

Those who are going to use the new heparins in practice, i.e. clinicians, are not interested in the technical discussion on the mechanism of action of the laboratory tests.
They want a figure that indicates the efficacy of antithrombotic treatment and a figure, preferably a different one, on the risk of bleeding.

From the above it is clear that the anti-Xa action is not likely to be useful as such a clinical parameter, especially in drugs like the LMWH where it is dissociated from other heparin properties. The antithrombin activity presents itself as an alternative. It is by no means sure that this is the pharmacologically important property either. There are many other actions of heparin that might in fact cause or influence the pharmacological activity of heparin. One might cite its inducing a tissue-factor VIIa inhibitor, its action on endothelial cells or platelets, its action on blood lipids, its action on fibrinolysis, etc.

Personally, I nevertheless have a tendency to reserve an important place for antithrombin action, be it only because it is the only known action of heparins that causes the same net effect (i.e. less thrombin) as another potent antithrombotic: oral anticoagulation.

Even though pharmacologically irrelevant, the anti-Xa action has one important advantage: it is very convenient to measure. In fact, it is often the only parameter that appears to change in the plasma of patients treated with LMWH. At its very best, however, this must be considered an epiphenomenon that changes together with the pharmacologically important property whatever that may be.

It is the very nature of fractionated heparin that, unlike unfractionated heparin, there are important shifts in the ratio of the different activities. No matter what the clinically important parameter may be, the ratio of its activity to any other measured activity must be assumed to vary from one LMWH prepa- 
ration to another. For each separate preparation the anti-factor Xa activity may be a convenient means to get an impression of the variations in the level of the pharmacologically important activity. For between-preparation comparison it is ipso facto useless.

Therefore, the anti-factor Xa-based comparison of a LMWH to a standard may be useful for the standardization of laboratory procedures but is no rational way to arrive at clinical comparability. This may be obvious to the specialist but it must be stressed in order not to induce a false sense of security among nonspecialized clinicians.

In order to develop the argument further it may be useful to recall the importance of platelet factor 4 (pf 4) neutralization of heparin.

In ideally prepared platelet-free plasma, such as is of course used by all those wishing to assess heparin levels (blood collected in platelet-inhibiting cocktail, first centrifugation at $15^{\circ} \mathrm{C}$, etc.) pf 4 does not play a role. In less ideally prepared plasma it will neutralize $0.05-0.25 \mathrm{U} / \mathrm{ml}$ of unfractionated heparin [7].

In vivo, and especially at the site of a thrombus, platelets shed pf 4 and neutralize heparin. Unfractionated heparin is very efficiently suppressed, LMWHs are less subject to this inactivation and to a different extent. The presence of (low-affinity) fractions with no or hardly any anti-IIa or anti-Xa activity of their own but that do bind to pf 4 may greatly modify the action of a LMWH in platelet-rich plasma and presumably in vivo.

Such differences would not be recognized by comparison of anti-Xa actions in plateletpoor plasma. Again the comparison of an unknown LMWH with the standard would fall short of clinical reality.
In my opinion the following considerations are essential for the reproducible characterization of a heparin preparation:

(1) It should be recognized that every heparin preparation has different activities that may contribute to its pharmacological efficacy in a different way. Probably the antithrombin activity and pf 4 susceptibility are important. The importance of anti-factor $\mathrm{Xa}$ activity can, on good grounds, be supposed to be minor.

(2) The behavior towards (AT III) heparin of activated clotting factors generated in clotting plasma is different from that of isolated clotting factors, even if the latter are added to plasma [5]. Tests based on the inactivation of added isolated factors should therefore be interpreted with caution.

(3) Comparing one single property of a LMWH fraction to a single property of a standard preparation may induce a false sense of security especially among the nonspecialists that are going to use the preparations in medical practice.

These considerations should not deter from establishing adequate standardization for the characterization of LMWH, but rather favor standardization that meets the requirements that can be foreseen on the basis of the present state of the art. That is, each heparin preparation should be characterized for its antithrombin activity, its pf 4 susceptibility and - for those who take a fancy to it - its anti-factor Xa activity. For clinical use it might be the best policy to indicate the strength of a LMWH on the basis of a property that is easy to measure and does not suggest understanding of the system beyond our present knowledge, i.e. weight per volume. Up to this moment one cannot blame the FDA and the German Government to adopt this position. 


\section{References}

1 Fareed, J.; Walenga, J.M.; Hoppensteadt, D.; Huan, X.; Racanelli, A.: Comparitive study on the in vitro and in vivo activities of seven low molecular weight heparins. Haemostasis 18: suppl. 3, pp. 3-15 (1988).

2 Fareed, J.; Hoppensteadt, D.; Walenga, J.M.; Huan, X.; Messmore, H.L.: Validity of the newly established low molecular weight heparin. Standard in cross referencing low molecular weight heparins. Haemostasis 18: suppl. 3, pp. 33-47 (1988).

3 Choay, J.; Petitou, M.; Lormeau, J.C.; Sinay, P.; Casu, B.J.; Gatti, G.: Structure-activity of relationship in heparin: a synthetic pentasaccharide with high affinity for antithrombin III and eliciting high anti-factor $X_{a}$ activity. Biochem. biophys. Res. Commun. 116: 492-499 (1983).

4 Béguin, S.; Lindhout, T.; Hemker, H.C.: The mode of action of heparin in plasma. Thromb. Haemostasis (in press, 1988).
5 Hemker, H.C.: The mode of action of heparin in plasma; in Verstaete, Vermylen, Lijnen, Arnout, Thrombosis and Haemostasis pp. 17-36 (Leuven University Press, Leuven 1987.

6 Walenga, J.M.; Fareed, J.; Petitou, M.; Samama, M.; Lormeau, J.C.; Choay, J.: Intravenous antithrombotic activity of a synthetic heparin polysaccharide in a human serum induced thrombosis model. Thromb. Res. 43: 243-248 (1986).

7 Putten, J. van; Ruit, M. van de; Beunis, M.; Hemker, H.C.: Heparin neutralization during collection and processing of blood inhibited by pyridoxal 5'-phosphate. Haemostasis 14: 253-261 (1984).

H.C. Hemker, Maastricht 